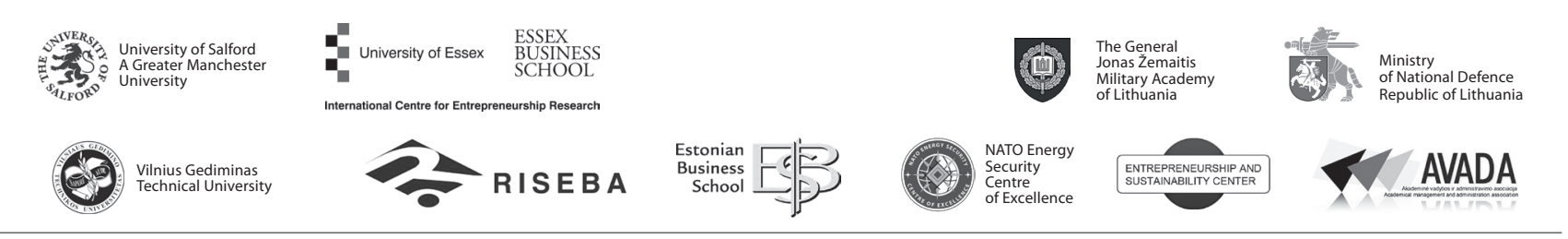

\author{
JOURNAL OF SECURITY AND SUSTAINABILITY ISSUES \\ ISSN 2029-7017 print/ISSN 2029-7025 online \\ 2018 March Volume 7 Number 3 \\ http://doi.org/10.9770/jssi.2018.7.3(15)
}

\title{
RECENT CHALLENGES OF INSTITUTIONAL IDENTITY AND CONTEMPORARY ARMED FORCES
}

\author{
Audronè Petrauskaité ${ }^{1}$, Tatjana Rusko ${ }^{2}$ \\ ${ }^{1}$ Department of Humanities, General Jonas Zemaitis Military Academy of Lithuania. \\ ${ }^{2}$ Department of Foreign Languages, Vilnius Gediminas Technical University, Lithuania \\ E-mails: ${ }^{1}$ audrone.petrauskaite@lka.lt; ${ }^{2}$ tatjana.rusko@vgtu.lt
}

Received 20 March 2017; accepted 26 January 2017

\begin{abstract}
Institutional identity is probably seen as the best and the only effective way for dealing with the uncertainties of postmodern society. The theory of institutional identity as positive interaction and development of personal and social identities and the foundation of self-image and self-esteem is especially important in the context of military organization. Defining or redefining the identity and its role in contemporary society has become the priority for the scientist. Mutable character of postmodern identity and identities' diversity put to inconvenience the traditional understanding of this phenomenon. The phenomenon of postmodern identity has brought some difficulties into creation of universal concept of institutional identity. Institutional identity of the Armed Forces is reasoned by the postmodern transformations of the society. Transformations in the Armed Forces (changes in mission, structure, woman's role, etc.) have shifted traditional identity of the militaries toward contemporary society: i.e. it has become multidimensional and fragmented. The process of creation of institutional identity in the Armed Forces should be based on peculiarities of postmodern individuals: rational way of thinking and their self-esteem.
\end{abstract}

Keywords: postmodernity, identity, institutional identity, contemporary society, contemporary Armed Forces, professional identity of the military, system of values

Reference to this paper should be made as follows: Petrauskaite, A.; Rusko, T. 2018. Recent challenges of institutional identity and contemporary armed forces, Journal of Security and Sustainability Issues 7(3): 559-566.

http://doi.org/10.9770/jssi.2018.7.3(15)

JEL Classifications: M12

\section{Introduction}

The institutional identity is one of the main factors of the stability of any organization - private or governmental. According to scholar standpoint (Tajfel 1981, 1982, Rughase 2016, Gioia et al.2013, etc.), institutional identity is based on individual perception of common mission, goals and values' orientation, common past and future perspective which means that institutional identity is founded on individual association with the organization. This association provides success and stability of the organization as well as it is the guarantee of personal satisfaction of its members. 
The process of globalization, rapid development of technologies and transformations in the identity and worldview of an individual has drastically changed management, structure and organizational relationships of any institution as well as it brought about many problems and difficulties for managers in pursuit of increasing the organization longevity. Nowadays, organizational identity is probably seen as the best and the only effective way for dealing with such uncertainties. Per contra, the process of globalization has raised the opposite process of society fragmentation based on the idea of individualization and localization. These processes have introduced some misunderstanding and confusion into the consciousness of both - individuals and society, at the same time affecting the institutional identity of the organizations (e.g. Luhn et al. 2017, Čirjevskis 2017).

The basis of military organization and its institutional identity is laying on the traditions, rooted in centuries. The system of values, mission and goals of such organization has more stable character that provides certain equilibrium to institutional identity of the military in our drastically changing world. Despite the above, contemporary transformations of the society are exerting influence on the identity of the militaries as well. The key question is the balance between personal identity of the individuals and the institutional identity of an organization: how to maintain individuality and construct a personal identity in the context of such a strong organizational identity as military one? The issue of interaction between institutional and personal identity is a topical scientific issue of contemporary psychology (Tajfel 1981, 1982, Battistelli 1997) and sociology. The most important question for the scientist is to find out the influence of the organization (both positive and negative) on the personal perception and assessment of the reality in the process of individualization and fragmentation of postmodern society. This question is currently central for military sociologists (Moskos et al. 2000) as well as military psychologists. The theory of institutional identity as positive interaction and development of personal and social identities and the foundation of self-image and self-esteem (Tajtel, Turner 1986) can raise numerous questions in the context of military organization. The construct of the military identity is used as mechanism to eliminate individualism and unify the organization aimed to accomplish its mission by means of strong discipline, common aims and collective responsibility. This mechanism disagrees with the main idea of contemporary paradigm of postmodern society denying the uniqueness of a person, his curiosity and responsibility.

The aim of this research is to analyze the processes and some peculiarities of collective identity of contemporary military with focus on the main factors influencing the process, namely, postmodernity and postmodern transformations of the society, identity and military. This analysis is made within the interdisciplinary context - i.e. philosophy and sociology. Thus, the methodology of the article is based on the structuralism and poststructuralism as philosophical theoretical background (Bauman, 1996, Foucault 1996), postmodern paradigm of the military (Moscoss 2000) and the concept of network society (Castels 2010).

\section{Postmodern identity as the issue of contemporary organization}

Postmodernity as world-wide characteristic of contemporary society is very complex and controversial. It can be characterized as global society, society of new technologies, network society, society of knowledge, etc. Most scientists keep up with such changes in the organization of social and economic life as time and space compression and acceleration of information, knowledge, communication, production and consumption (Ericsen 1997, 2003), as new ways of communication and getting information (Castels 2010) as well as economic and cultural fragmentation of the society (Friedman 1997, 2004). All these changes influence the identity of contemporary society.

According to M. Castells, introduction and spreading of new technologies and intensive process of globalization of the 21-st century has brought about new type of getting information and communication framing a new type of society - "network society". New forms of material life, space and time are creating new forms of identity (both collective and individual) and a new type of organization - networking organization. Transformations going on in economy, politics and social life are not unanimous: world-wide network, various forms of globalism and cosmopolitanism are going hand in hand with the opposite process, - that of localization and singularity. Manuel Castells argues that traditional forms of collective identity of contemporary society are in crisis (Castels 2010). The same critical tendencies in the formation of postmodern identity are emphasized by 
Janathan Friedman and Thomas Hylland Eriksen. Both of them have noted the process of localization and fragmentation of a society in the era of globalization. (Friedman 1997, 2004; Eriksen 2007).

At the end of 20th century the changes in the identity of the society became evident, and controversial. The transformations have been reflected in all spheres of human's life as well as have become the challenge for the society. The issues of the identity have posed some riddle for academics and become the object of research in different sciences - philosophical, sociological, historical, psychological, anthropological, linguistic, etc. Without considering a different methodological bases and various approaches to the characteristics of contemporary identity and the directions of its development, the most important scientific questions are: How to define the identity? What is the difference between modern and postmodern identity? Can we talk about the "crisis of identity" in contemporary society?

Stuart Hall defines three concepts of identity (Hall 1996). According to classical sociological conception, the identity is formed in the process of interaction between individuals and society as the continuous dialog and as the gap between personal and individual world. The Enlightenment conception of the identity is based on the human person as a fully centered, unified individual, endowed with the capacities of reason, consciousness, and action, which is creating his identity as self-esteem during all his existence. Postmodern concept of identity denies having a unified and stable identity and experiences it as fragmented, composed of several, sometimes contradictory identities, being formed and transformed continuously. Mutable character of postmodern identity and the diversity of identities put to inconvenience traditional understanding of this phenomenon.

Researchers face the challenge of defining both the identity and its role in the life of an individual. First of all it became difficult task for the philosophers, sociologists and psychologists. Understanding identity and its framing as a personal goal to guarantee more stable existence turned out to be unsound. Instability in economy, political and social life has forced people to migration and more flexible lifestyle. It's east to change the place of residence, job or country in our globalized and unpredictable world. With such a flexible lifestyle and mobility, it is difficult for a person to maintain close relationships with any community (local or national) and organization (social and institutional). Under these circumstances there are lots of people with "vagabond" or "tourist" consciousness. According to Zygmunt Bauman the "tourist" "is everywhere he goes in, but nowhere of the place he is in" (Bauman 1996, p.26). Thus, objective processes resulted in the identity (as interaction of an individual and society) to become more unstable, more fragmented and time limited. According to Douglas Kellner "identity today becomes a freely chosen game, a theatrical presentation of the self" (Kellner 1992). Hence, the postmodern identity is just an imitation that an individual attempts to perceive continuously in unstable present world. All discussions on identity are in fact just the issue of identity disappearance because of its fragmentation and uncertainty.

The process of transformations and reconstruction of the identity in contemporary society is becoming problematic not only because it is being redefined or hardly defined. There are some debates on the role of identity in the development of a society. Some researchers point out that the fundamental problem of post-modern identity is not its unrest or instability, but rather a large fixation. Hence, the "modern "problem of identity" was how to construct an identity and preserve it solid and stable, the postmodern "problem of identity" is primarily how to avoid fixation and keep options open" (Bauman 1996, p.18 ). According to Zygmunt Bauman, postmodern instability has introduced a new challenge for both - the individuals and societies. This means that identity, as both individual aim and task to escape uncertainty, has got a lot of trainers, coaches, consultants and teachers knowing what kind of identity could be required and created (Bauman 1996). Thus, individual freedom of choice and creativity in coining individual identity is confined by experts' guidance.

Society imposes some limitations on individuals in their life strategy, value orientations and behavior - that is "must-have" preconditions of the survival of society and the basis for the stability in human's life. According to Foucault, identity is the creation of power-knowledge (the way power circulation creates discursive fields which finally shape the identity), meaning that individuals form their identity producing knowledge in the realm of social communication and mutual interaction. The positive result of this power-interaction is institu- 
tional identity (Foucault 1996, p.27). In any case, interaction of individuals and society in identity formation may usher in both the advantages and disadvantages to both sides. Disadvantages can be hidden in the situation when "the kind of society we live in limits such strategies as may critically and militantly question its principles and thus open the way to new strategies, currently excluded because of their non-viability"(Bauman Z., 1996, p. 37). The role of society (or community/institution) can be dangerous in postmodernity when "the world is catching up with the vagabond, and catching up fast and "the world is re-tailoring itself to the measure of the vagabond" (Bauman 1996, p.26). Zygmunt Bauman's "vagabond" does not mean the person who can't find the place to settle down but the person who doesn't belong to any community, any organization or institution, the person who is "open to any proposals" and who filled postmodern world with his system of values and life strategy.

"Vagabond's" identity and its interaction with the collective identity has introduced changes in society as well. Personal skills, professional experience and knowledge are not very important criterions for human evaluation in postmodern society because of the fast changing requirements of global labour market as well as the dominant "vagabond" identity. Such kind of flexibility doesn't let establish the strategy with future perspective for a lengthy period of time or have more stable development trend of the society (or community/institution). It ultimately results in speeding up the fast changing character of contemporary world.

Undoubtedly the phenomenon of postmodern identity is manifested in the issues of institutional identity as well. It has introduced some misunderstanding to the process of institutional identity formation. There exist a lot of scientific concepts on the process of formation and development of institutional identity which were shaped after extensive empirical research in this field. Nevertheless, the institutional identity still remains an enigma for scientists (Gioia et al. 2013). According to the researchers a lot of questions are waiting to be answered: "Do we have a good understanding of all the relevant processes involved in identity formation?", "Why is institutional identity difficult to change?", "Why is institutional identity changing so fast?", "How can such an essential concept of institutional identity apparently be both immutable and mutable?", etc. (Gioia et al. 2013, p. 84). The mystery in the formation of institutional identity is hidden in the mystery of postmodern society. All attempts to create universal concept of institutional identity or to have universal model of its formation face the complexity of postmodern society and unpredictability of changes in economy, politics and social life which are reasoned by technological progress and globalization. The concept of institutional identity is based on the phenomenon of postmodern identity which denies the universality and constructiveness as well as the possibility of creating a common model of identity.

\section{Postmodern identity in the military}

What kind of transformations are taking place in the Armed Forces and how are they reflected in military identity? According to C. C. Moscoss paradigm of postmodern military, the Armed Forces have faced new challenges under the transformations of the society at the end of the 20th and at the beginning of the 21st century. Political transformations and new forms of threats caused new security issues. Simultaneously the processes of feminization, democratization, specialization and integration have become more intensive and evident in Western societies. Altogether the above had an impact on individual attitudes to family, organization, nation, state and society. These changes have affected Western military as an organization. C. C. Moskos singled out 11 indicators to distinguish the development stages of the military in the 20th century, i e.: Perceived Threat, Force Structure, Major Mission Definition, Dominant Military Professional, Public Attitude, Media Relations, Civilian Employees, Women`s Role, Spouse and Military, Homosexuals in Military, Conscientious Objection. The focus will be kept on 6 of them (threat, structure, mission, women's role, spouse and civilians employees in the military) which, in our opinion, had the greatest influence on the changes of institutional identity of the Armed Forces in postmodern society (Moskos 2000; Hogg 2001).

Traditional institutional identity of the military was centered on the system of patriotic values (nation, country, sacrifice, etc.) because the main and the greatest mission of the Armed Forces was to defend the country and its people, to fight enemies. The end of the 20th and the beginning of the 21 st centuries changed the traditional 
point of view. Subnational, asymmetric and hybrid character of postmodern threats changed the mission of the military and its structure: currently military missions are varied and the structure of the Armed Forces is based on professional militaries (not on conscript service). This has led to some confusion into identity of the militaries: who are we - warriors or peacemakers, fighters or defenders?

International character of NATO and collective defense system resulted in some duality in institutional identity of the military as well: national Armed Forces are an integral part of collective defense system of the Alliance as well as an integral part of national defense system. The question arises: What kind of institution are the Armed Forces of the state: national, international or both? Defining the representation of the institution is one of the main issues of institutional identity, being essential for the organization itself and every member.

Traditional institutional identity of the military has always been predominantly masculine-oriented because of traditional composition of the Armed Forces based on physiological peculiarities of the men. The requirements for gender equality and changes in professional assignments have changed the composition of the military: the Armed Forces became diverse in gender and lost its distinction as masculine organization. Subsequently, contemporary identity of the military is losing its traditional image of a strong and courageous soldier-man.

Traditionally the Armed Forces were a very sheltered and isolated from the society organization. There were minimum civilian employees and maximum military in the structure. The families of the officers were fully integrated into military life. Such isolation of the military organization was reasoned by specific role and mission of the Armed Forces during the centuries. The development of the democracy as well as the development of the military profession gave rise to more civilians working as professionals in the Armed Forces. Is has transformed institutional identity of the Armed forces as rather subordinated and strongly disciplined organization toward more human-orientated one.

The family is another important factor influencing the conscience of the military person. Traditionally the officer's family was fully integrated in the life of military organization ("officer's wife", "officer's children", "officer's family" - meant that family members mentally belonged to the military person and his organization as well). Officer's family had been separated from the military and started living their own life in contemporary society. Thus, officer's life has changed and is currently realized in two spheres - professional and private ones. Such division introduced essential change to institutional identity of the Armed Forces making it a more typical professional organization. Consequently, a military person has become rather a professional military worker than a military servant: "from 8 till 5 I am a military, later on- a father, husband, son, etc." Under these circumstances the question arises: how should institutional identity of the Armed Forces be constructed in postmodern society?

According to Manuel Castells "it is easy to agree to the fact that...all identities are constructed. The construction of the identity uses building material from history, geography, biology, productive and reproductive institutions, collective memory and personal fantasies, power apparatus and religious revelations. But individuals, social groups and societies process all these materials and rearrange their essence according to social determinations and cultural projects that are rooted in their social structure and in their space/time framework" (Castells 2010, p. 8). The theory of postmodern identity creation, as opposed to the theory of essential identity, discusses identity as a multidimensional and fragmented object. So the changes into the institutional identity of the Armed Forces are natural ones and are going in line with the transformations of the society.

The process of institutional identity creation in postmodern Armed Forces should be focused on two aspects: the role of the institution and the role of individuals in this process. Traditionally the Armed Forces, as one of the state actors, are trying to keep strong control over identity building process. As a rule this process is making use of sources from history, collective memory, traditions of the institution and the system of professional military values. The military organization focuses on strengthening emotional motivation of both the militaries and the organization in this process. Is emotional motivation enough for the individuals serving in the Armed Forces under the circumstances of postmodernity? 
There are few types of motivation of the individuals for military service - patriotic and/or civic motivation, material and postmodern motivation (Battistelli 1997, Griffith 2008). Patriotic motivation is based on the system of individual values oriented to the defense of the country and society. Material motivation is typical for modern society and related to the interests of social security, material stability and career development. Postmodern motivation is based on the assurance of hobbies and self-expression capabilities of the person. According to the results of tests conducted in Lithuanian Armed Forces, the motivation of Lithuanian militaries is based on different types of individual motivation to serve in the military: there are patriotic and material motives as well as motives to get new knowledge and experience, to have opportunity for self-expression and for self-exercise (Vileikienè et al. 2015). It is also important to note that the motives of interests in military arts and the military as a way of life are uniting all groups of individuals and gives main sense to the service in the Lithuanian Armed Forces. According to the above-mentioned test results it could be noted that postmodernity has brought about changes into the process of identity creation, thus postmodern identity of the military has become obvious. Hypothetically it is assumed that the number of individuals belonging to the group of individuals with postmodern motivation will grow (currently it is about $50 \%$ of the respondents). That means new challenges for institutional identity of Lithuanian military which is traditionally oriented on patriotic and civic values or material motives.

Postmodern individuals are creating their identity rather on the basis of rational than emotional background. So the institutional identity of the Armed Forces must be built on postmodern and more rational background giving the opportunity for self-expression. The ways of self-expression of the individuals in the military should be rooted in their knowledge and professional competences. According to Brook Manville and Josiah Ober (Manville, Ober 2003), the organizational identity can neither be imposed nor introduced, but must be derived from the beliefs, values and actions of the employees themselves, including those who seek to earn the right to be called real leaders. The Armed Forces should give individuals the chance to create their identity alongside with creation of postmodern institutional identity of the militaries.

\section{Conclusions}

Postmodern concept of identity denies unified and stable identity of both a person and society. Mutable character of postmodern identity and the diversity of identities is at variance with traditional understanding of this phenomenon. The process of transformations and reconstruction of the identity in contemporary society has become the problem for individuals, society and every institution as well.

All attempts to create universal concept of institutional identity or to have universal model of its formation face the complexity of postmodern society and unpredictability of changes in economy, politics and social life reasoned by technological progress and globalization. The construction of institutional identity has encountered two mutually supportive and determinant phenomena - fragmentation and fixation of identity which became the main issue for the organization and society as the obstacle for further development.

The issues of institutional identity of the Armed Forces are influenced by the postmodern transformations of the society and changes in its politics, economy and social life. Changes in mission and structure, increased woman's role in the military, etc. have shifted traditional identity of the militaries toward contemporary society: it has become multidimensional and fragmented. As well as the motivation of contemporary individuals to serve in the army is based on more rational than emotional reasons, the aim to create institutional identity in the Armed Forces should be grounded on peculiarities of postmodern individuals: rational way of thinking and their self-esteem. 


\section{References}

Battistelli F. 1997. Peacekeeping and the Postmodern Soldier, Armed forces \& Society, 23(3): 467-484.

Bauman Z. 1996. From Pilgrim to Tourist - or a Short History of Identity. Questions of Cultural Identity. Ed. Stuart Hall and Paul du Gay. London: Sage Publications, p.18-37.

Castells M. 2010. The Power of Identity. UK. Blackwell Publishing,

Čirjevskis, A. 2017. Acquisition based dynamic capabilities and reinvention of business models: bridging two perspectives together, Entrepreneurship and Sustainability Issues 4(4): 516-525. https://doi.org/10.9770/jesi.2017.4.4(9)

Eriksen, T. H. 1993. Ethnicity and Nationalism. London: Pluto Press.

Eriksen, T. H. 2007. Globalization. The Key Concepts. London: Bloomsbury.

Foucault M. 1996. Discipline and Punish. The Birth of the Prison. USA, Second Vintage Book Edition.

Franke, V. C. 2001. Generation X and the military: A comparison of attitudes and values between West Point cadets and college students, Journal of Political and Military Sociology 29: 92-119.

Friedman, J. 1997. Global crises, the Struggle for cultural Identity and Intellectual Porkbarrelling: cosmopolitans Versus Locals, Ethnics and Nationals in an Era of De-Hegemonisation./ Werbner, P., Modood, T. (eds.) Debating Cultural Hybridity. Multi-Cultural Identities and the Politics of Anti- Racism: 70-89. London: zedBooks.

Friedman, J. 2004. Globalization, Transnationalization, and Migration: Ideologies and Realities of global Transformation./ Friedman, J., Randeria, S. (eds.) Worlds on the Move. Globalization, Migration and Cultural Security: 63-90. London: I. B. Tauris.

Gioia, D.A. 2008. Organizational identity as an emerging perennial domain./ Sage handbook of new approaches in manage-ment and organization D. Barry \& H. Hansen (Eds.). Los Angeles, CA: Sage Publications, p.63-65. https://www.researchgate.net/publication/262853067_Organizational_Identity_Formation_and_Change

Gioia, D.A.; Patvardhan, S. D.; Hamilton, A.L.; Corley K.L. 2013. Organizational identity formation and change, The Academy of Management Annals 7(1): 123-192.

Griffith, J. 2008. After 9/11, what kind of reserve soldier? Considerations given to emerging demands, organizational orientation, and individual commitment, Armed Forces \& Society 35: 214-240.

Grojean, M., W., Thomas, J., L. 2006. From values to performance: It's the journey that changes the traveler./The Psychology of serving in peace and combat: Military Culture./T. W. Britt, A. B. Adler, C. A. Castro (Eds.). London: Praeger Security International, p. $35-59$.

Hall St. 1996. The Question of Cultural Identity./ Modernity. An Introduction to Modern Societies./ Edited by Stuart Hall, David Held, Don Hubert, and Kenneth Thompson. Oxford. The Open University press, 1996. p. 596-632.

Hogg, Michael A. A. 2001. Social Identity Theory of Leadership, Personality and Social Psychology Review 5(3): $184-200$.

Huntington, S. P. 1957. The soldier and the State. London: The Belknap Press of Harvard.

Kellner Douglas. 1992. Popular culture and constructing postmodern identities / Scott Lasch and Jonathan Friedman (eds). Modernity and Identity. Oxford: Basil Blackwell.

Luhn, A.; Aslanyan, S.; Leopoldseder, C.; Priess, P. 2017. An evaluation of knowledge management system's components and its financial and non-financial implications, Entrepreneurship and Sustainability Issues 5(2): 315-329. https://doi.org/10.9770/jesi.2017.5.2(11)

Manville B., Ober J. 2003. Beyond Empowerment: Building a Company of Citizens, Harward Buisness Review.

Moskos, C.C., Williams, J. A., \& Segal, D. R. 2000. Armed forces after the cold war./ C.C. Moskos, J. A. Willams, \& D. R. Segal (Eds.), The postmodern military: Armed forces after the cold war (pp. 1-13). New York: Oxford University Press.

Rughase, Olaf. G. 2006 Identity and strategy: How individual visions enable the design of a market strategy that works. Cheltenham: Edward Elgar Publishing.

Tajfel H. 1981. Human Groups and Social Categories: Studies in Social Psychology. Cambridge:CambridgeUniv. Press. 1369 p.

Tajfel, H. 1982. Social Psychology of Intergroup Relations, Annual Rewiev Psycology 33:1- 39 
Van Dick, R., Wagner, U., Stellmacher, O.C., \& Christ, O. 2005. To be(long) or not to be(long): Social identification in organizational contexts, Genetic, Social and General Psychology Monographs 13: 189-218.

Vileikienė E., Pocienė A., Aleknevičienė J..2015. Motyvacija tarnauti Lietuvos kariuomenejje: mokslo studija [Motivation to serve in the Lithuanian Armed Forces: research studio], Generolo Jono Žemaičio Lietuvos karo akademija.

Audrone PETRAUSKAITE, PhD, is an assoc. prof. in the department of Humanities of General Jonas Zemaitis Military Academy of Lithuania. She is the coordinator of the Master degree study programme "Security and Defense of the Society". Scientific interests: military ethics, civic education, national security, issues of postmodern military.

Tatjana RUSKO, PhD, is an assoc. prof. of the Department of Foreign Languages at Vilnius Gediminas Technical University. Scientific interests include discourse analysis, pragmatics, semantics, sociology, ethics, philosophy, communication. 